\title{
I Would Like to Be Truthful, But...: A Systemic Study of Academic Dishonesty From Conscientiousness, Performance Goal Orientation, Competition, and Peer Influence Perspectives
}

\author{
Dyah Ayu Kusumawardani Gunawan and Andrian Pramadi \\ Faculty of Psychology \\ Universitas Surabaya
}

\begin{abstract}
Academic dishonesty is any behavior in the learning process which violates the principles of justice and integrity, in order to get higher marks. The complexity of the phenomenon requires a systemic analysis which considers individual and contextual factors. This research used the incidental sampling survey method. The research subjects were 535 Faculty of Psychology students from the 2013 to 2016 classes of Universitas Surabaya. The research goal was to examine the role of individual factors, including conscientiousness and performance goal orientation, and also contextual factors, including competition and peer influence, regarding academic cheating. The research results showed that conscientiousness, performance goal orientation, competition, and peer influence together contributed to academic cheating in the amount of $11.6 \%(R=.340, p=.000)$. The analysis of each factor showed that there are three factors influencing academic cheating, these being conscientiousness (partial correlation $=-.262, p=.000)$, competition (partial correlation $=.129, p=.003$ ), and peer influence (partial correlation $=.189, p=.000$ ). However, performance goal orientation did not play any role (partial correlation $=.066, p=.128$ ). This implied the existence of other factors, such as self-efficacy, academic achievement, and university regulations.
\end{abstract}

\section{Keywords: academic dishonesty, conscientiousness, performance goal orientation, competition, competitive climate, peer influence}

\begin{abstract}
Kecurangan akademis merupakan perbuatan dalam proses belajar yang melanggar prinsip keadilan dan kebenaran, dengan tujuan mendapatkan nilai lebih tinggi. Kompleksitas fenomena ini menuntut kajian sistemis yang mempertimbangkan faktor individual dan kontekstual. Penelitian ini dilakukan dengan metode survei incidental sampling. Subjek penelitian adalah 535 mahasiswa Fakultas Psikologi Universitas Surabaya angkatan 2013 hingga 2016. Tujuan penelitian adalah melihat peranan faktor individual yaitu kepribadian conscientiousness dan performance goal orientation, serta faktor konstekstual yaitu kompetisi dan pengaruh teman terhadap kecurangan akademis. Hasil penelitian menunjukkan conscientiousness, performance goal orientation, kompetisi, dan pengaruh teman secara bersama-sama berperan terhadap kecurangan akademis sebesar $11.6 \%(R=.340, p=.000)$. Analisis tiaptiap faktor menunjukkan tiga faktor yang berperan yaitu conscientiousness (korelasi parsial $=-.262, p=.000)$, kompetisi (korelasi parsial $=.129, p=.003)$, dan pengaruh teman $(\mathrm{ko}$ relasi parsial $=.189, p=.000)$. Akan tetapi, performance goal orientation kurang berperan (korelasi parsial $=.066, p=.128$ ). Hal ini menunjukkan adanya kontribusi faktor lain yang perlu diteliti seperti self-efficacy, pencapaian akademis, dan peraturan universitas.
\end{abstract}

Kata kunci: kecurangan akademis, conscientiousness, performance goal orientation, kompetisi, iklim kompetisi, pengaruh teman

Cheating behavior has spread like a virus in the world of global education (Khodaie, Mochadamzadeh,

Correspondence concerning this article should be addressed to Dyah Ayu Kusumawardani, Faculty of Psychology Universitas Surabaya Jalan Raya Rungkut Mejoyo (Kalirungkut) Surabaya 60293. E-mail: dyahayu gunawan@gmail.com
\& Salehi, 2011; Nora \& Zhang, 2010). Even years before, Nagy (2009) and Magnus, Polterovich, Danilov, and Savvateev made the same conclusion (2002), that cheating behavior is an epidemic which has spread across culture and the world of education. College students who cheat will get higher marks by imple- 
menting dishonest methods; and this will affect not only themselves, but also the academic climate overall. Students who commit academic cheating, even if only once, are inclined to cheat again in the future (Stuber-McEwen, Wiseley, \& Hoggatt, 2009). Cheating behavior will be committed not only in the academic setting, but also in the workplace (Graves, 2011; Nazir, Aslam, \& Nawaz, 2011).

The context of the classroom discusses pedagogical issues. Poor pedagogy and the implementation of a competitive system lead to the belief that cheating behavior is more the fault of lecturers than that of a student (Bong, 2008; Murdock, Beauchamp, \& Hinton, 2008). Basically, the competitive situation created by lecturers can influence cheating behavior. Lecturers who do not demonstrate the importance of the learning process and of student progress, as well as who demand excessively high standards, tend to increase the possibility that students will cheat (E. M. Anderman \& Anderman, 2009).

A greater impact is that upon educational institutions and the educational system. When students engage in cheating, they not only violate their personal integrity, but also stain the university's reputation (Engler, Landau, \& Epstein, 2008; Happel \& Jennings, 2008). In the educational system, cheating hinders the accomplishment of the principle mission of education, that being the transfer of knowledge, by allowing students to graduate without mastering that knowledge (Bouville, 2010; Szerdahelyi, 2008; Van Yperen, Hamstra, \& Van der Klauw, 2011). Thus, cheating decreases the efficiency of the educational system of a nation, because cheating distorts competition, decreases the motivation of students' to learn, and creates an innacurate evaluation of students' abilities (Magnus et al., 2002).

The spread of academic cheating has caused a number of researchers to map an illustration of the phenomenon on a national scale. McCabe (2005), Lin and Wen (2007), together with the Litbang (Indonesian abbreviation, Penelitian dan Pengembangan Research and Development) Media Group (Pujiastuti, 2012) constitute a group of researchers and a research institution which has attempted to investigate the level of academic cheating in the United States and Canada, Taiwan, and Indonesia. Table 1 provides the depiction of the research results.

The phenomenon of academic cheating has also occurred in the Faculty of Psychology of Universitas Surabaya. This was disclosed through data from the results of initial interviews with four students. A preliminary study succeeded in identifying types of a- cademic cheating committed by the the subjects, including cheating on tests or quizzes, and assignments. This supported the findings of McCabe, Butterfield, and Trevino (2012) and McCabe (2005), which indicated the same varieties of academic cheating. Another type of cheating which was not identified in research conducted by McCabe, but which is still relevant to academic cheating, is asking or helping another student to sign the class attendance list, without asking the lecturer's permission. This behavior still meets the criteria of academic cheating, according to E. M. Anderman and Anderman (2009), who stated that academic dishonesty is an effort to convince others that a person has more skill, abilities, and potential than he or she really has, or has performed more academic endeavour than that actually done. Attendance at class is one aspect of evaluation in the learning process, in the Faculty of Psychology of Universitas Surabaya. When a student asks another to sign for him or her on the attendance list, despite the fact that he or she did not attend, that student has claimed to have made an academic endeavour which was actually not performed. Besides this, there were also four factors which comprise the principle causes of academic cheating in tertiary student circles.

Students with individual factors in the form of personalities demonstrating low conscientiousness, have poorer organization, self-control, and lack the habit of working hard, and a sense of responsibility. When these students undertake education, they tend to have less of a desire, and make less effort, to master lesson materials, and are less prepared to face the academic cycle (Eshet, Grinautski, Peled, \& Barczyk, 2014; P. Okanović, Okanović, Mitrović, \& Majstorović, 2013; Siaputra, 2013; Williams, Nathanson, \& Paulhus, 2010). Further to this, students who are devotees of performance goal orientation, are more focused on comparing their achievements with those of others, and less concerned about their own learning process. Their main goal is to win, or not to fail, in the academic context, by employing various means (Anderman \& Danner, 2008; Anderman \& Murdock, 2007; Tas \& Tekkaya, 2010).

Peer groups (both large and small), which are a contextual factor, have a big influence on the behavior and belief of their devotees. When a tertiary student perceives academic cheating as something appropriate, or even obligatory, he or she will have a tendency to adopt the same sort of behavior (Carrell, Malmstrom, \& West, 2008; McCabe et al., 2012; Rettinger \& Kramer, 2009). Furthermore, the com- 
Table 1

A Comparison of the Prevalence of Academic Cheating on a National Scale in the US and Canada, Taiwan, and Indonesia

\begin{tabular}{|c|c|c|c|}
\hline Researchers & Nation & Sample & Research Results \\
\hline $\begin{array}{l}\text { McCabe } \\
(2005)\end{array}$ & $\begin{array}{l}\text { United States } \\
\text { and Canada }\end{array}$ & $\begin{array}{c}71,071 \\
\text { undergrad. } \\
\text { students }\end{array}$ & $\begin{array}{l}\text { There were many types of academic cheating committed with various } \\
\text { prevalences ( } 9 \% \text { to } 42 \%) \text {, inter-alia:, obtaining test questions from } \\
\text { someone who has already taken the exam; surreptitious copying from } \\
\text { another student during a test, with or without their knowledge; working } \\
\text { with others on an assignment when asked for individual work; para- } \\
\text { phrasing or copying of a number of sentences, without citing the source, } \\
\text { and fabricating or falsifying bibliography. }\end{array}$ \\
\hline
\end{tabular}

\begin{tabular}{|c|c|c|c|}
\hline $\begin{array}{l}\text { Lin \& Wen } \\
(2007)\end{array}$ & Taiwan & $\begin{array}{l}2,068 \\
\text { undergrad. } \\
\text { students }\end{array}$ & $\begin{array}{l}\text { The prevalence of academic cheating including cheating at the time of } \\
\text { a test, cheating on assignments, plagiary, and falsification of docu- } \\
\text { ments, was } 61.72 \% \text {. }\end{array}$ \\
\hline $\begin{array}{l}\text { Litbang } \\
\text { Media } \\
\text { Group } \\
\text { (Pudjiastuti, } \\
\text { 2012) }\end{array}$ & $\begin{array}{c}\text { Indonesia } \\
\text { (Makassar, } \\
\text { Surabaya, } \\
\text { Yogyakarta, } \\
\text { Bandung, } \\
\text { Jakarta, and } \\
\text { Medan) }\end{array}$ & $\begin{array}{c}480 \text { adult } \\
\text { respondents } \\
(\geq 17 \text { years } \\
\text { old })\end{array}$ & $\begin{array}{l}\text { The percentage of respondents who claimed to have cheated when at } \\
\text { high school or university was } 70 \% \text {. }\end{array}$ \\
\hline
\end{tabular}

petition factor will make students demonstrate their abilities through good marks, and by winning the social competition, regarding the results of their learning (Brown \& Emmet, 2001; Orosz, Farkas, \& RolandLévy, 2013).

A low level of conscientiousness, a high level of motivation regarding performance goal orientation, membership of a peer group which commits academic cheating, and high level of competition, will produce students with a tendency to seek the easiest way, with the perception that any method may be used to achieve better results, compared to other students. Moreover, students with a combination of these individual and contextual factors will face various types of assessment, such as examinations and assignments. In the end, if a student encounters opportunities to cheat within the academic cycle, he or she will tend to chose to commit that academic cheating.

In this way, a number of research questions emerge, one of those being: what is the role of these four variables in academic cheating, both jointly and individually? This research is aimed at looking at the role of the individual factors, those being a conscientious personality and performance goal orientation, together with contextual factors, such as competition and the influence of associates, regarding academic cheating. The major hypothesis of this research is that conscientiousness, performance goal orientation, competition, and peer influence, together play a significant role in academic cheating. The first minor hypothesis of the research is that the lower the conscientiousness level, the higher the level of academic cheating committed by the student. The second minor hypothesis is that the higher the performance goal orientation level, the higher the level of academic cheating committed by the student. The third hypothesis of the research is that the higher the level of competition, the higher the level of academic cheating committed by the student. Finally, the fourth hypothesis is that the higher the level of peer influence, the higher the level of academic cheating.

\section{Method}

\section{Participants}

The population of this research was undergraduate level students from the 2013, 2014, 2015, and 2016 commencement year groups from the Faculty of Psychology at Universitas Surabaya, who were still active during the even-numbered semester of 2016/2017; and who were taking one or more of the following courses: Application of Assessment and Intervention: Family, Application of Assessment and Intervention: Industry and Organizations, Theories and Techniques of Interventions: Training, Psychological Measurement (Achievement Test), and the Sociology and Anthropology 
of Urban Society. The minimal number of subjects was 100 from each subject, in order to maintain the validity and reliability of the measurement instruments. The reason for choosing the sample from existing subjects is related to the relevance of the student experience with academic cheating. At the time of the conduct of this research, these students were still actively involved in the learning processes, such as learning in the classroom, taking exams and quizzes, and completing assignments.

\section{Procedure}

The data was collected from a total of 535 tertiary students online through <tinyurl.com/surveikc>, and by offline survey. Data collection utilized the incidental sampling technique. The process of preparation and collection of data was as follows:

(1) Identification of courses prepared to have their data collected;

(2) Conduct of informal interviews with classroom assistants from each subject, in regards to the learning processes and forms of evaluation conducted throughout the semester;

(3) Requesting of permission from the responsible lecturer, and other lecturers teaching the same subject in parallel classes, which had been chosen for data collection;

(4) Explanation of the aim of the research, then provision of a statement concerning a guarantee of secrecy for the information;

(5) Explanation of the process for completion of the online and offline surveys.

\section{Measurement}

This study utilized six types of measurement instruments, modified by the researchers to fit the characteristics of the sample. Four of the six instruments are:

(1) The Big Five Inventory, consisting of nine items related to the dimensions of conscientiousness (Surijah \& Sia, 2007);

(2) The Pattern of Adaptive Learning Scales, consisting of six items related to the dimensions of performance-approach, and four items related to performance-avoid, to measure performance goal orientation (Midgley et al., 2000);

(3) The Individual Differences in Competitiveness Scale, consisting of four items related to Hypercompetition, four items related to self-developmental competition, and four items related to positive attitudes towards competition, all of which are used to measure competitiveness;

(4) The Competitive Climate Scale, consisting of three items related to constructive competition, and three items related to destructive competition, used to measure the competitive climate which is used in the supplementary analysis for competition variables (Orosz et al., 2013).

Each item of the four measurement instruments was answered by selecting one of six choices, on the basis of the Likert scale ( 1 = "Strongly Inappropriate", 2 = "Inappropriate", 3 = "Somewhat Inappropriate", 4 = "Somewhat Appropriate", 5 = "Appropriate", and $6=$ "Very Appropriate"). Scoring was performed by calculating the mean value of each measurement instrument. However, in the Individual Differences in Competitiveness Scale, the scoring was obtained by calculating the average of the mean of each dimension.

Further to these, the two other measurement instruments were:

(1) Endogenous Peer Effects, consisting of eight items relating to the dimensions of peer influence (Carrell et al., 2008);

(2) The McCabe Academic Integrity Scale, consisting of 26 items relating to academic cheating (McCabe \& Trevino, 1993).

The two items of the measurement instruments were answered by selecting one of the choices of answers, based on the six-point Likert Scale. ( 1 = "Never", 2 = "Rarely", 3 = "Sometimes", 4 = "Often", 5 = "Very Often", and $6=$ "Always"). Scoring was conducted by calculating the mean value of each measurement instrument.

\section{Analysis Plan}

This research conducted validity testing using the Content Validity Response (CVR) method, against three 'raters', who were also lecturers from the Faculty of Psychology at the University of Surabaya, together with a cognitive process interview method, against ten students of the Faculty of Psychology of Universitas Surabaya (three students who began their study in 2013, two in 2014, two in 2015, and three in 2016). The data analysis in the research was conducted using the IBM SPSS Statistics, Version 20 for Mac, program, for testing of reliability, testing of assumptions, and analysis of regression. The regression method which was used is to click on enter. This method analyzed the role of all independent variables against dependent variables, both those having significant influences, as well as those not (Sugiyono \& 
Table 2

Correlation and Reliability Values of All Scales Used in This Study

\begin{tabular}{|c|c|c|c|c|}
\hline No. & Scale & Number of Item & $r$ Item Factor & Reliability Coefficient \\
\hline 1. & Conscientiousness & 9 & $.215-.469$ & .732 \\
\hline 2. & $\begin{array}{l}\text { Performance Goal Orientation } \\
\text { (Performance-Approach) }\end{array}$ & 5 & $.609-.754$ & .878 \\
\hline 3. & $\begin{array}{l}\text { Performance Goal Orientation } \\
\text { (Performance-Avoid) }\end{array}$ & 5 & $.610-.712$ & .826 \\
\hline 4. & $\begin{array}{l}\text { Individual differences in competition scale } \\
\text { (Hypercompetition) }\end{array}$ & 4 & $.510-.709$ & .791 \\
\hline 5. & $\begin{array}{l}\text { Individual differences in competition scale } \\
\text { (Self-developmental competition) }\end{array}$ & 4 & $.717-.819$ & .892 \\
\hline 6. & $\begin{array}{l}\text { Individual differences in competition scale } \\
\text { (Positive attidues towards competition) }\end{array}$ & 4 & $.653-.716$ & .870 \\
\hline 7. & $\begin{array}{l}\text { Competitive climate scale (Constructive } \\
\text { Comptition) }\end{array}$ & 3 & $.360-.570$ & .745 \\
\hline 8. & $\begin{array}{l}\text { Competitive climate scale (Destructive } \\
\text { Comptition) }-3 \text { items }\end{array}$ & 3 & $.401-.494$ & 645 \\
\hline 9. & $\begin{array}{l}\text { Competitive climate scale (Destructive } \\
\text { Competition) }-2 \text { items }\end{array}$ & 2 & .446 & 617 \\
\hline 10. & Endogenous peer effects & 8 & $.414-.631$ & .808 \\
\hline 11. & Academic Cheating & 26 & $.403-.788$ & .940 \\
\hline
\end{tabular}

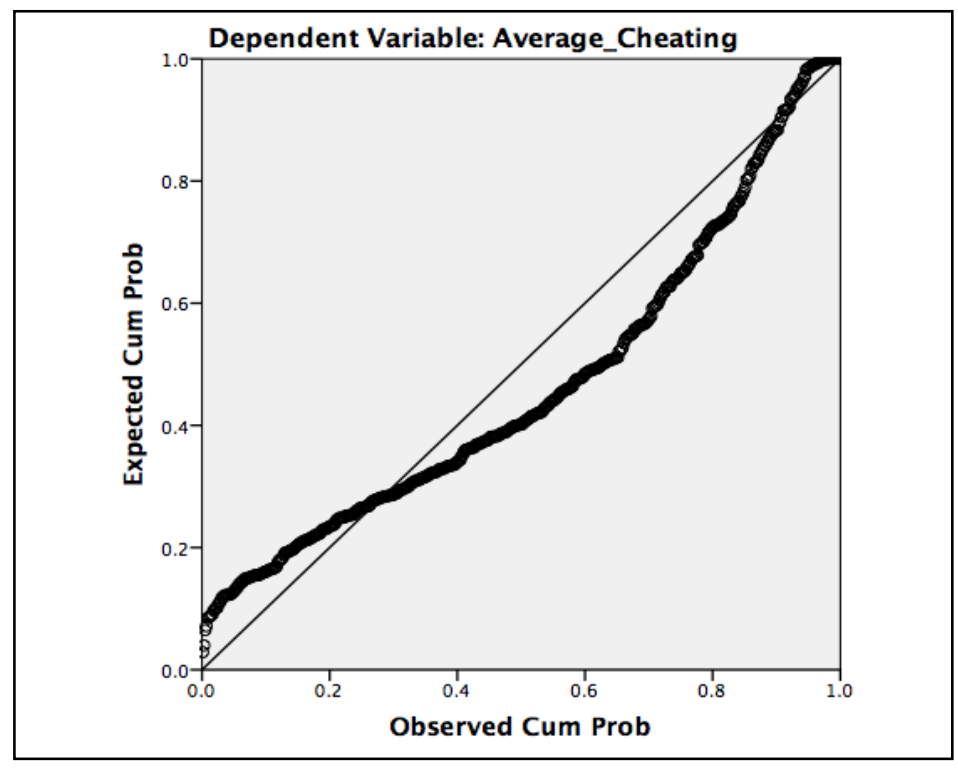

Figure 1. Normality based on Normal P-P Plot.

Susanto, 2015). Finally, this multiple regression test should produce a model and a commonality with multiple linear regression.

(a) Testing of item validity. The results of the CVR, using the Lawshe CVR method on three experts (panelists), through rational analysis, showed that 11 out of the 64 original survey items needed improvement. Besides this, the panelists still made comments, and suggested improvements to items which had in fact already been considered suitable, particularly in the matter of language. The total number of items on the measurement instruments after revision, was 71 , which were then subjected to response process analysis testing. The response stage for the ten students showed that 13 survey items and instructions for survey completion needed to be improved. There was no change 
in the number of items from this process.

The reliability testing of measurement instruments, which was used in this study, was by tried experimental methods. This means that measurement testing was obtained from the data of the real subjects. All aspects of each measurement instrument were reliable. Table 2 provides the results of the reliability testing.

(b) Assumption testing. Multi-collinearity testing, using VIF and Tolerance, showed that conscientiousness $(V I F=1.119 ;$ tolerance $=.894)$, performance goal orientation $(V I F=1.437$; tolerance $=.696)$, competition $(V I F=1.524 ;$ tolerance $=.656)$, and peer influence $(V I F=1.012 ;$ tolerance $=.988)$ all had VIF values of $<5$ and a tolerance of $>0.1$. Thus, no problem of multicollinearity was found.

Auto-correlation testing using Durbin-Watson, with a significance value of .05 , showed that the DurbinWatson $(D W)$ value was 1.965 . The Durbin-Watson table $(D U)$ for 535 subjects is 1.86929 . Thus, $D W 1.965$ $>D U 1.86929$, which means that no positive auto-correlation was found. Thus $5-D W$ was 3.035 , and 3.035 $>D U 1.86929$. Hence negative autocorrelation was not found. In conclusion, no problem of auto-correlation was found.
Normality testing using PP-Plot normals showed that the data was abnormal (Figure 1). This was supported by the results of the normality testing in Table 3, which showed the spread of abnormal data from all variables was classed as abnormal. The literature has indicated that data with abnormal distribution may still be studied using parametric methods. The reasons were: violations of normality assumptions have no significant impact on statistical testing results (Schatschneider \& Lonigan, 2010); furthermore, normality is basically a relative matter, because there are, as yet, no standards related to the distortion of reality, considered significant or extreme, agreed to by interresearch guidelines (Schatschneider \& Lonigan, 2010); and, in a large sample, minor deviatons from the normal would be considered statistically significant, whereas such deviations would not influence the results of parametric testing (Öztuna, Elhan, \& Tüccar, 2006; Widhiarso, 2012). This was very relevant to this research which had a large sample size, that is, 535 subjects.

The interpretation of regression linearity in Table 4 showed that the value of the significance of each independent variable was $<0.05$. Thus it may be concluded that the relationship between academic che-

Table 3

Results of Normality Testing

\begin{tabular}{llcc}
\hline No. & \multicolumn{1}{c}{ Variable } & Kolmogorov-Smirnov $\rho$ & Status of Data Distribution \\
\hline 1. & Conscientiousness & .000 & Abnormal \\
2. & Performance goal orientation & .000 & Abnormal \\
3. & Competition & .000 & Abnormal \\
4. & Peer Influence & .004 & Abnormal \\
5. & Academic Cheating & .000 & Abnormal \\
\hline
\end{tabular}

Table 4

Result of Linearity Testing, Between Academic Dishonesty and Independent Variables

\begin{tabular}{llll}
\hline No. & \multicolumn{1}{c}{ Variable } & Sig. & Linearity Status \\
\hline 1. & Conscientiousness & .000 & Linear \\
2. & Performance goal orientation & .008 & Linear \\
3. & Competition & .003 & Linear \\
4. & Peer Influence & .000 & Linear \\
\hline
\end{tabular}

Table 5

Result of Regression Testing Between Independent and Dependent Variables

\begin{tabular}{llcccr}
\hline No. & \multicolumn{1}{c}{ Variable } & \multirow{2}{*}{ Sig. } & \multicolumn{2}{c}{ Correlation } \\
\\
\hline 1. & Conscientiousness & -0.270 & .000 & -.198 & -.262 \\
2. & Performance goal orientation & 0.075 & .128 & .113 & .066 \\
3. & Competition & 0.151 & .003 & .124 & .129 \\
4. & Peer Influence & 0.182 & .000 & .194 & .189 \\
\hline
\end{tabular}




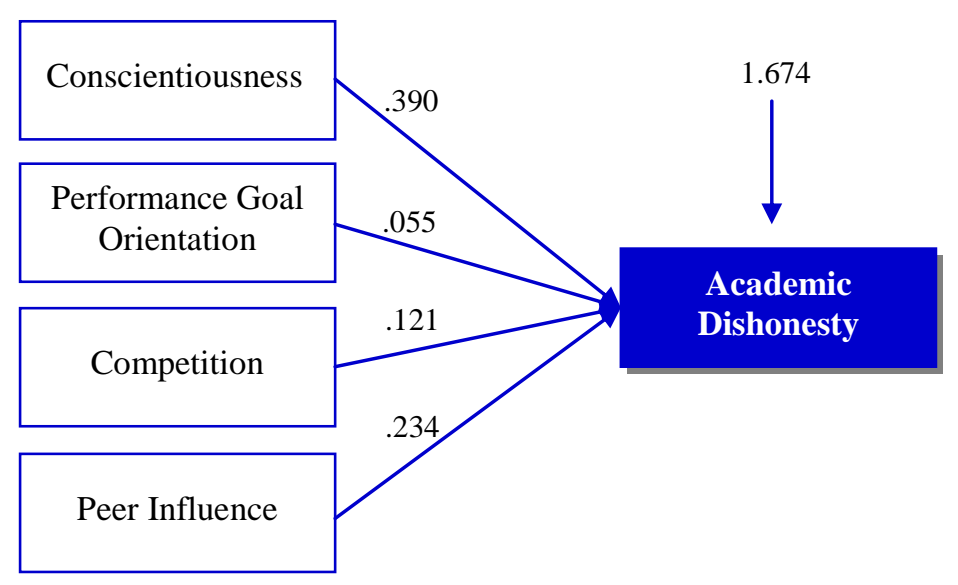

Figure 2. The multiple regression model of academic cheating.

ating and conscientiousness, performance goal orientation, competition, and peer influence fulfilled the requirements of linearity.

\section{Testing of Hypotheses}

The multiple correlations between conscientiousness, performance goal orientation, competition, and peer influence together, relating to academic cheati$\mathrm{ng}$, was sufficient, that is, .340. The determinating coefficient $\left(R^{2}\right)$ was .116 , meaning that the independent variable role percentage against the change in the dependent variable was $11.6 \%$. The significance of the ANOVA testing was $.000(\leq .05)$, indicating that the independent variables had a role related to the dependent variables. Thus, the major hypothe-sis was accepted, that is, the conscientiousness, performance goal orientation, competition, and peer pressure variables, together, have a role related to academic cheating. The multiple regression equation generated was $Y=1.674-0.309 X 1+0.055 X 2+0.121$ $X 3+0.234 X 4$ (Figure 2).

The result of regression testing in Table 5 indicated that the partial correlation value of conscientiousness was - $262(p=.000)$. The negative value of the regression coefficient showed that students with lower conscientiousness levels have a higher level of academic cheating. In conclusion, the first minor hypothesis in this study is accepted.

Furthermore, the partial correlation value of performance goal orientation had a value of .066 ( $p=.128)$. The significance value $>.05$ indicated that performance goal orientation did not have a role related to academic cheating. In conclusion, the second minor hypothesis in this study is rejected.
The correlation between hypercompetition, selfdevelopmental competition, and positive attitude towards competition, showed quite high and significant results; thus, the three of these cannot be distinguished one from the other. The same thing can also be seen from the correlation between the climates of destructive and constructive competition $(r=.601, p=.000)$. Thus, researchers combined the mean value from the means of the three types of competition in the hypothesis testing.

The partial correlation value of competition was $.129(p=.03)$. This showed that the higher the level of competition of an individual, the higher the level of academic cheating. In conclusion, the third minor hypothesis in this study is accepted.

Finally, the partial correlation value of peer influence was $.189(p=.000)$. This showed that the higher the peer influence level, the higher the academic cheating level. In conclusion, the fourth minor hypothesis in this research is accepted.

Zero-order correlation between conscientiousness and academic cheating was - .198. When other variables were controlled (partial correlation), correlation increased to become - .262. Furthermore, zero-order correlation between performance goal orientation and academic cheating was .113. When other variables were controlled (partial correlation), the correlation decreased to .066. Then, the zero-order correlation between competition and academic cheating was .124. When other independent variables were controlled (partial correlation), the correlation increased to .129. Lastly, zero-order correlation between peer influence and academic dishonesty was .194. When other independent variables were controlled (partial correlation), the correlation decreased to .189 . 
Correlation testing between constructive and destructive competitive climates showed that both were significantly correlated at a moderate level $(r=.407$, $p=.000$ ). This indicated that, basically, the two variables measured the same thing, that is, the competitive climate. The implication is that regression testing by combining the two types of competitive climate.

Correlation testing between competitive climate and individual competition showed the value of $r=$ .730 and of $p=.000$. This result indicated that the two of these have a high and significant correlation. Thus, one may interpret this as indicating that both variables measured basically the same thing.

Regression testing using the stepwise method, for competitive climate and competition for academic dishonesty, was conducted, to see the role dynamics between the two variables, regarding academic cheating. Regression testing results showed that it was only the competitive climate which had a significant role contributing to academic dishonesty (partial correlation $=.140, p=.001)$. This supported the findings of this research, that the competitive climate variable could accommodate the role of individual competition in regard to academic cheating.

Further study considered the role of each competitive climate, regarding academic cheating. Regression testing showed that the destructive competitive climate was more effective in predicting academic cheating (partial correlation $=.125, p=.004$ ). Conversely, constructive competition was less than effective in predicting academic cheating (partial correlation $=.043, p=.322$ ). Thus, destructive competition was the more dominant variable in determining a tendency towards academic cheating, compared to constructive competition.

\section{Discussion}

A multiple correlation $(R)$ between conscientiousness, performance goal orientation, competition, and peer influence together, regarding academic cheating, was satisfactory, that is, at .340. The determination coeffeicient $\left(R^{2}\right)$ value was .116 , meaning that the percentage of the role of the independent variables regarding the change in dependent variables was $11.6 \%$, whereas the remainder $(88.4 \%)$ was affected by other internal and contextual variables, such as academic achievement (McCabe et al., 2012), socialeconomic status (McCabe \& Trevino, 1997), risk-taking behavior (McCabe et al., 2012), self-efficacy (Jurdi, Hage, \& Chow, 2011), neutralization techni- ques (E. J. Park, Park, \& Jang, 2013), university regulations (McCabe \& Trevino, 1993), and factors relating to reward and deterrence (Isakov \& Tripathy, 2017; McCabe, Feghali, \& Abdallah, 2008). This shows that academic dishonesty is a very complex phenomenon, so that it is very necessary to study this in a systemic manner. The ANOVA testing significance value was 0.000 . Thus, the variables of conscientiousness, performance goal orientation, competition, and peer influence together have a role regarding academic cheating.

If a student possesses the factors related to a personality containing conscientiousness, together with motivation oriented towards performance goal orientation, and is faced with contextual factors such as peer groups which commit academic cheating, as well as competitive learning environment, he or she, when undergoing an evaluative process, will increasingly tend to demonstrate cheating behavior, when there is an opportunity to do so.

Regression testing results in Table 4 show that conscientiousness had a partial correlation value of - .262 $(p=.000)$. The value of the negative regression coefficient showed that students having low conscientiousness values tended to an increasing level of academic cheating. Conscientiousness is the personality term used to describe someone with a tendency towards neatness and organization, who has self-control, works hard, and is responsible (Roberts, Lejuez, Krueger, Richards, \& Hill, 2014). A low level of conscientiousness will lead to impulsiveness, as well as poor discipline and lack of the self-control needed not to commit academic cheating (Giluk \& Postlethwaite, 2015; Okanović et al., 2013). This is explained through the Temporal Motivation Theory (TMT) component, which indicates that the impulsiveness of students with low conscientiousness will lead them to avoid their responsibilities to learn, by engaging in other activites (Siaputra, 2013). When a student is easily distracted, he or she tends to be impulsive and will eventually procrastinate. As a result, the time for his or her obligatory study responsibilities will become increasingly short. Having little time, the student must still complete the same amount of work. Finally, to overcome the pressure, this student will turn to cheating methods, as a way out of the problem (Giluk \& Postlethwaite, 2015). A lazy student will also manifest low self-control and organization, so that, when facing deadlines for assignments, or/and exams, he or she will tend not to demonstrate any endeavour, and instead choose more to commit academic cheating, to compensate for the lack of endeavour 
he or she has produced (Giluk \& Postlethwaite, 2015; Okanović et al., 2013). This is aimed at obtaining better marks than he or she should have achieved.

The partial correlation value of the performance goal orientation was $.066(p=.128)$. The significance value of $>.05$ showed that performance goal orientation did not have a role in academic cheating. This means that the nature of the relationship between the two was indirect. Research by Van Yperen et al. (2011) measured the relationship between performance goal orientation and academic dishonesty, in a number of situations (achievement settings). The results showed that individuals may have different goals in different situations, as a response to different demands and expectations. This showed that the goal orientation of a person is largely determined by the context faced (Anderman \& Danner, 2008). Even though specific study subjects had already been selected for the subject year groups, this research examined only illustrations of performance goal orientation in general, and did not consider the existence of any specific contextual role (such as classroom pedagogy, classroom goal orientation) regarding the existence of the personal goal orientation of students. Furthermore, collectivity and high social orientation have a specific impact on the motivation orientation of Asian tertiary students. A collective culture will lead individuals to use the standards and goal orientation sourced from others- such as parents and teachers ( $\mathrm{Li}$, 2002). Thus, the interpretation of performance goal orientation in Asian students is not always bad, because, such an orientation to the meeting of social demands is seen as a good thing, and in accordance with social norms, so that this type of motivation is widely adopted to encourage students to achieve good performances (Macayan, 2012). Specific contextual variables such as classroom goal orientation, or cultural characteristics, have the potential to be mediating variables towards performance goal orientation, regarding academic cheating.

Competition had a partial correlation value of .129 $(p=.03)$. This showed that the higher the competition level of an individual, the higher the level of academic cheating committed. Competition is the perception and attitude of a student concerning his or her involvement in the learning process, which elicits competitive behavior, based on a strong desire to win against other students (E. M. Anderman \& Anderman, 2009; Orosz et al., 2013). Competition originates from the presence of internal and external pressures to succeed academically (Sarma, 2014). Students with high levels of competitiveness have to confront other students in the academic world, within which the assessment process is to be found. A very high desire to win this inter-student competition eventually leads them to ignore faculty rules, provided that this can enable them to defeat other students (Brown \& Emmet, 2001).

Studies on the relationship between the competitive climate and individual competition showed a high correlation $(r=.730, p=.000)$. This correlation showed that both variables measure basically the same thing. When performing stepwise regression, only one variable was discovered which could significantly predict academic dishonesty, namely the competitive climate (partial correlation $=.140, p=.001$ ). This supports the research by $\mathrm{Li}$, which showed that the collective culture of Asian societies has a very great influence on the individual (Chen, 2015), including regarding academic demands. The personal goal orientation of students is related to their perception of the classroom and faculty-level goal structure (Anderman \& Danner, 2008). Besides this, the role of parents in forming educational goals is also great, emerging in the form of external academic demands demanding high standards of achievement (Chen, 2015). Environmental influences, such as these, again increased by student collectivity, lead them to tend to adopt the same personal goals as those of the environmental, classroom, and faculty goal structures (Anderman \& Danner, 2008), so that finally this directs their behavior (such as cheating) to achieving certain goals (achieving high marks). In conclusion, the role of the climate is bigger, compared to individual competition, and is able to contain an individual competitive role, in determining the tendencies of an individual to cheat.

Further analysis showed that the destructive competition climate was more effective in predicting academic cheating (partial correlation $=.125, p=.004$ ) than the constructive competition climate (zero-order correlation $=.102$, partial correlation $=.043, p=$ .322). As described earlier, the personal goal orientation of a student is related to the academic climate in the faculty (Anderman \& Danner, 2008). This research was conducted in a faculty which tends to emphasize a destructive competitive climate. This can be viewed from several aspects. Firstly, there is an orientation towards gaining high marks, in the form of 65 or $\mathrm{C}$ as the minimum grade to pass each subject, exam, and assignment. Secondly, the Competence Based Curriculum (Indonesian - Kurikulum Berbasis Kompetensi) system combines the credit loads of several subjects into one subject. If students fail, they 
have to retake the subject, with large credit loads, and are unable to take other courses. Thirdly, there is a student marking system called the Indeks Prestasi Semester (Semester Achievement Index - IPS), by which the achiever of the highest overall mark in each year group will win a curricular scholarship. These three things reflect the research results of Wideman (2008) and Anderman and Murdock (as cited in Orosz et al., 2013), showing that a learning environment which develops competition will give incentives to winners; that is, praise, scholarships, and other exclusive advantages. Students who wish to receive incentives if they win competitions are more likely to commit academic cheating. In this case, if the importance of the incentive is higher than the importance of the assignment itself, students may view academic cheating as acceptable. Furthermore, destructive competition involves anger and envy, as well as dishonest and distrusting relationship with rivals. Winners would pride themselves, and the losers would accuse the winners of cheating and being dishonest (Fülöp \& Orosz, 2015). When the class or faculty greatly emphasizes on grade and highly appreciate high achievements (by giving students praises and scholarships), students would compete destructively.

Students in a competitive climate will feel great environmental pressure to make great achievements (Wideman, 2008). When these students also have a high individual level of competition, the pressure to defeat other students will become greater (Williams $\&$ Sheridan, 2010). Finally, in order to overcome the demands they have, students will be more likely to use dishonest means to win against the competition (Brown \& Emmet, 2001).

Finally, the partial correlation value of peer influence was $.189(p=.000)$. This shows that the higher the peer influence, the higher the level of academic cheating. Peer influence refers to the academic cheating patterns or behaviors which are perceived by students, from others, as being something easy, interesting, and which may overcome problems rela-ted to marks (Carrell, Malmstrom, \& West, 2008). Through a social learning process (Bandura, 1986), students may learn cheating methods by observing, remembering, attempting to mimic, and by receiving reinforcement (positive responses) from their environment, to commit academic cheating. Besides this, a student may choose to commit academic cheating because of, on previous occasions, observing his or her peers doing the same thing and receiving pleasing effects, such as high marks (O'Fallon \&
Butterfield, 2012). This is exacerbated when the same individual enters a close-peer group environment which supports cheating behaviour. He or she may learn techniques, a motive, and approving attitudes, because there are neutralization and rationalization processes of deviant behavior, as well as the receipt of support from associates (MacGregor \& Stuebs, 2012). Thus, as demonstrated by these research results, the extent of the peer influence a person has may lead to higher personal tendencies towards academic cheating (Carrell et al., 2008).

The perception of the academic cheating committed by his or her peers is one of the strongest factors in establishing academic cheating (McCabe et al., 2012). Through the perception mechanism, a student learns academic cheating, not only by observation, but also by gaining normative support from the cheating behavior of peers (McCabe \& Trevino, 1993). Thus, cheating may be regarded as a necessity, and be adopted as a normal method to attain or maintain good marks. This research shows that $53.1 \%$ of students were classified in the categories of Quite High, High, and Very High, in terms of peer influence. This indicates that the subject students felt quite high degrees of peer influence, in their learning activities.

This research had the goal of examining the role of the factors which systematically contributed to the emergence of academic dishonesty; that is, individual factors, having a personality demonstrating conscientiousness, and performance goal orientation, as well as contextual factors, that is, competition and peer influence. In general, conscientiousness, performance goal orientation, competition, and peer influence together, contributed significantly to academic cheating. Specifically, conscientiousness, competition, and peer influence each contributed to the commission of academic cheating; whereas, performance goal orientation did not have any considerable role.

The results of this research showed that personality factors contributed more to academic dishonesty than other variables. However, motivation factors had less of a role in academic cheating. There are still other individual factors which might be explored in future research, such as self-efficacy, ethical characteristics, risk-taking, and morality.

\section{Limitations}

There were some shortcomings in this research, such as the quite large number of survey items, the data collection process, which was conducted at the 
end of lectures, which made subjects rush to fill in surveys, and the lack of an open survey to ask questions about other factors contributing to academic cheating. This tended to make the subjects less serious, when completing the items, and there was also the lack of study into other factors which might contribute to academic cheating. Another shortcoming was the small number of CVR panelists involved (three experts) who came from the faculty being studied. This might have made possible the emergence of bias, as it revealed academic cheating on the part of their students.

\section{Conclusions and Suggestions}

Academic cheating is a highly complex phenomenon, and so requires systematic or multi-factorial stu$\mathrm{dy}$. The emergence of academic dishonesty is determined not solely by individual factors, so it is very important to take into account factors outside the individual, which also play a role, such as competition and peer influence. Besides their large roles, contextual factors may also modulate the roles of individual factors. Other contextual factors, which have yet not been studied in this research, are university regulations, the role of teachers or lecturers, together with factors relating to reward and deterrence. Researchers into academic cheating, who wish to study contextual factors, have to consider the academic sphere, conditions, and academic context of the research subjects.

In conclusion, the complexity of academic cheating requires that this phenomenon be studied using a systematic approach, considering individual and contextual factors. Future research needs also to consider other independent variables, which have not been examined in this research, such as age, academic achievement, involvement in extra-curricular activites, socioeconomic status, risk-taking behavior, self-efficacy, university regulations, and factors related to reward and deterrence.

A suggestion which is made to the faculty of psychology, is to design activities which promote conscientiousness, such as self-control training, self-organization seminars, and also the implementing awarding of positive reinforcements to students who manifest characteristics of conscientiousness. Later, the faculty may also need to develop constructive competition, and to apply collaborative learning methods, which give students the opportunities to build comprehension, elucidation, or solutions within their own learning processes. Following that, educational institutions generally need to develop more specific and clearer regulations related to academic cheating, to increase the role of educators (control by lecturers) as a means of exerting external pressure in reducing academic cheating, and also to develop sustainable programs of academic integrity, conducted on an ongoing basis.

\section{References}

Anderman, E. M., \& Anderman, L. H. (2009). Psychology of classroom learning: An encyclopedia. Detroit: Macmillan Reference USA/Gale Cengage Learning.

Anderman, E. M., \& Danner, F. (2008). Achievement goals and academic cheating. Revue internationale de psychologie sociale, 21(1), 155-180.

Anderman, E. M., \& Murdock, T. B. (2007). Psychology of academic cheating. Amsterdam: Elsevier Academic Press.

Bandura, A. (1986). Social foundations of thought and action: A social cognitive theory. Englewood Cliffs, NJ: Prentice Hall.

Bong, M. (2008). Effects of parent-child relationships and classroom goal structures on motivation, helpseeking avoidance, and cheating. The Journal of Experimental Education, 76(2), 191-217.

Bouville, M. (2010). Why is cheating wrong? Studies in Philosophy and Education, 29(1), 67-76.

Brown, B. S., \& Emmett, D. (2001). Explaining variations in the level of academic dishonesty in studies of college students: Some new evidence. College Student Journal, 35(4), 529-539.

Carrell, S. E., Malmstrom, F. V., \& West, J. E. (2008). Peer effects in academic cheating. Journal of Human Resources, 43(1), 173-207.

Chen, W. W. (2015). The relations between perceived parenting styles and academic achievement in Hong Kong: The mediating role of students' goal orientations. Learning and Individual Differences, 37, 48-54.

Engler, J. N., Landau, J. D., \& Epstein, M. (2008). Keeping up with the Joneses: Students' perceptions of academically dishonest behavior. Teaching of Psychology, 35(2), 99-102.

Eshet, Y., Grinautski, K., Peled, Y., \& Barczyk, C. (2014). No more excuses-personality traits and academic dishonesty in online courses. Journal of Statistical Science and Application, 2, 111-118.

Fülöp, M., \& Orosz, G. (2015, May 15). State of the art in competition research. In R. Scott \& Kosslyn (Eds.), Emerging trends in the social and behavi- 
oral sciences. Hoboken, New Jersey: John Wiley \& Sons, Inc.

Giluk, T. L., \& Postlethwaite, B. E. (2015). Big Five personality and academic dishonesty: A meta-analytic review. Personality and Individual Differences, 72, 59-67.

Graves, S. M. (2011). Student cheating habits: A predictor of workplace deviance. Journal of Diversity Management (JDM), 3(1), 15-22. https://doi.org/10. 19030/jdm.v3i1.4977

Happel, S. K., \& Jennings, M. M. (2008). An economic analysis of academic dishonesty and its deterrence in higher education. Journal of Legal Studies Education, 25(2), 183-214.

Isakov, M., \& Tripathy, A. (2017). Behavioral correlates of cheating: Environmental specificity and reward expectation. PloS one, 12(10), e0186054. https://doi.org/10.1371/ journal.pone.0186054

Jurdi, R., Hage, H. S., \& Chow, H. P. (2011). Academic dishonesty in the Canadian classroom: Behaviours of a sample of university students. The $\mathrm{Ca}$ nadian Journal of Higher Education, 41(3), 1-35.

Khodaie, E., Moghadamzadeh, A., \& Salehi, K. (2011). Factors affecting the probability of academic cheating school students in Tehran. Procedia-Social and Behavioral Sciences, 29, 1587-1595.

Li, J. (2002). A cultural model of learning Chinese "Heart and mind for wanting to learn". Journal of Cross-Cultural Psychology, 33(3), 248-269.

Lin, C. S., \& Wen, L. M. (2007). Academic dishonesty in higher education--a nationwide study in Taiwan. Higher Education, 54(1), 85-97. Retrieved from https://doi.org/10.1007/s10734-006-9047-z

Macayan, J. (2012). Asians' conception of achievement goals: An analytic review. The Official Research Journal of MIT, 1, 1-11. Retrieved from https:// www.academia.edu/7059773/Asians_Conception _of_Achievement_Goals_An_Analytic_Review.

MacGregor, J., \& Stuebs, M. (2012). To cheat or not to cheat: Rationalizing academic impropriety. Accounting Education, 21(3), 265-287.

Magnus, J. R., Polterovich, V. M., Danilov, D. L., \& Savvateev, A. V. (2002). Tolerance of cheating: An analysis across countries. The Journal of Economic Education, 33(2), 125-135.

McCabe, D. L. (2005). Cheating among college and university students: A North American perspective. International Journal for Educational Integrity, $1(1)$.

McCabe, D. L., \& Trevino, L. K., (1993). Academic dishonesty: Honor codes and other contextual influences. Journal of Higher Education, 64(5), 521-538.
McCabe, D. L., \& Trevino, L. K. (1997). Individual and contextual influences on academic dishonesty: A multicampus investigation. Research in Higher Education, 38(3), 379-396.

McCabe, D. L., Butterfield, K. D., \& Trevino, L. K. (2012). Cheating in college: Why students do it and what educators can do about it. Baltimore, Maryland: The John Hopkins University Press.

McCabe, D. L., Feghali, T., \& Abdallah, H. (2008). Academic dishonesty in the Middle East: Individual and contextual factors. Research in Higher Education, 49(5), 451-467.

Midgley, C., Maehr, M. L., Hruda, L. Z., Anderman, E., Anderman, L., Freeman, K. E., \& Urdan, T. (2000). Manual for the patterns of adaptive learning scales. Ann Arbor, 1001, 48109-1259.

Murdock, T. B., Beauchamp, A. S., \& Hinton, A. M. (2008). Predictors of cheating and cheating attributions: Does classroom context influence cheating and blame for cheating?. European Journal of Psychology of Education, 23(4), 477.

Nagy, J. (2009). Market forces in higher education: Cheating and the student-centred learning paradigm. In Ethical Practices and Implications in Distance Learning (pp. 249-267). IGI Global.

Nazir, M. S., Aslam, M. S., \& Nawaz, M. M. (2011). Can demography predict academic dishonest behaviors of students? A case of Pakistan. International Education Studies, 4(2), 208.

Nora, W. L. Y., \& Zhang, K. C. (2010). Motives of cheating among secondary students: The role of self-efficacy and peer influence. Asia Pacific Education Review, 11(4), 573-584.

O'Fallon, M. J., \& Butterfield, K. D. (2012). The influence of unethical peer behavior on observers' unethical behavior: A social cognitive perspective. Journal of Business Ethics, 109(2), 117-131.

Okanović, P., Okanović, D., Mitrović, D., \& Majstorović, N. (2013). Academic integrity "captured" by a personality-based test. Psihologija, 46(1), 61-75.

Orosz, G., Farkas, D., \& Roland-Lévy, C. (2013). Are competition and extrinsic motivation reliable predictors of academic cheating? Frontiers in Psychology, 4, 87. https://doi.org/10.3389/fpsyg.201 3.00087

Öztuna, D., Elhan, A. H., \& Tüccar, E. (2006). Investigation of four different normality tests in terms of Type 1 error rate and power under different distributions. Turkish Journal of Medical Sciences, 36(3), 171-176.

Park, E. J., Park, S., \& Jang, I. S. (2013). Academic cheating among nursing students. Nurse Education 
Today, 33(4), 346-352.

Pudjiastuti, E. (2012). Hubungan "self efficacy" dengan perilaku mencontek mahasiswa psikologi. Mimbar, 28(1), 103-112.

Rettinger, D. A., \& Kramer, Y. (2009). Situational and personal causes of student cheating. Research in Higher Education, 50(3), 293-313.

Roberts, B. W., Lejuez, C., Krueger, R. F., Richards, J. M., \& Hill, P. L. (2014). What is conscientiousness and how can it be assessed? Developmental Psychology, 50(5), 1315-1330.

Sarma, A. (2014). Parental Pressure for Academic Success in India (Doctoral dissertation, Arizona State University, 2014). Retrieved from https://re pository.asu.edu/attachments/137354/content/Sar ma_asu_0010E_14259.pdf

Schatschneider, C., \& Lonigan, C. J. (2010). Misunderstood statistical assumptions undermine criticism of the National Early Literacy Panel's Report. Educational Researcher, 39(4), 347-351.

Siaputra, I. B. (2013). The 4PA of plagiarism: A psycho-academic profile of plagiarists. International Journal for Educational Integrity, 9(2), 50-59.

Stuber-McEwen, D., Wiseley, P., \& Hoggatt, S. (2009). Point, click, and cheat: Frequency and type of academic dishonesty in the virtual classroom. Online Journal of Distance Learning Administration, 12 (3), 1-10.

Sugiyono, \& Susanto, A. (2015). Cara mudah belajar SPSS \& Lisrel. Bandung, Jawa Barat: Alfabeta.

Surijah, E. A., \& Sia, T. (2007). Mahasiswa versus tugas: Prokrastinasi akademik dan conscientious- ness. Anima Indonesian Psychological Journal, 22 (4), 352-374.

Szerdahelyi, J. (2008). Video technology for academic integrity in online courses. In P. Zemliansky \& K. St. Amant (Eds.), Handbook of research on virtual workplaces and the new nature of business practices (pp. 289-300). Hershey, Pennsylvania: IGI Global.

Tas, Y., \& Tekkaya, C. (2010). Personal and contextual factors associated with students' cheating in science. The Journal of Experimental Education, 78(4), 440-463.

Van Yperen, N. W., Hamstra, M. R., \& Van der Klauw, M. (2011). To win, or not to lose, at any cost: The impact of achievement goals on cheating. British Journal of Management, 22(1), S5-S15.

Widhiarso, W. (2012). Tanya jawab tentang uji normalitas. Retrieved from http://widhiarso.staff.ugm. ac.id/wp/tanya-jawab-tentang-uji-normalitas/

Wideman, M. A. (2008). Academic dishonesty in postsecondary education: A literature review. Transformative Dialogues: Teaching \& Learning Journal, 2(1), 1-12.

Williams, K. M., Nathanson, C., \& Paulhus, D. L. (2010). Identifying and profiling scholastic cheaters: Their personalities, cognitive ability, and motivation. Journal of Experimental Psychology: Applied, 16(3), 293-307.

Williams, P., \& Sheridan, S. (2010). Conditions for collaborative learning and constructive competition in school. Educational Research, 52(4), 335-350. 